\title{
WATER QUALITY DURING PRE-MONSOON AND POST- MONSOON AND MODELLING OF TOTAL DISSOLVED SOLIDS FOR TAMIRAPARANI RIVER, TAMILNADU, INDIA
}

\author{
D. Justus Reymond and Karuppasamy Sudalaimuthu ${ }^{\bowtie}$ \\ Department of Civil Engineering, SRM Institute of Science and Technology, SRM Nagar, \\ Kattankulathur, Kanchipuram, Chennai, TN, India, 603203. \\ ${ }^{\circledR}$ Corresponding Author: karuppas@srmist.edu.in
}

\begin{abstract}
The research was performed to investigate the water quality of Tamiraparani river situated in the district of Tirunelveli and Tuticorin, from source to sea. The river is about 128 kilometers long and is the only perennial river in Tamil Nadu. The samples were collected from 12 major places Papanasam, Cheranmadevi, Kokirakulam, Murapanadu, Thiruvidaimarudur, Ambasamudram, Authoor, Eral, Kallidai Kurichi, Srivaikuntam, Vellakovil and Sivalaperi. To understand the water quality, parameters were identified via the examination of $\mathrm{pH}$, turbidity, alkalinity, chloride, hardness, calcium, magnesium and TDS. Test results showed that the analyzed parameters were within the World Health Organization's allowable limits. Although the parameters of water were in the acceptable range, the overall findings indicate that the effects on the wetland environment should be best addressed. From the results obtained, the average WQI is calculated to be 64.1 which falls borderline. This indicates the poor quality of the river due to the presence of pollutants. Prediction of total dissolved solids was performed with the results using MATLAB. These WQI results point to take required actions to avoid water pollution and TDS predication will be useful for planning and managing water quality.
\end{abstract}

Keywords: Water Quality, Monsoon, Water Quality Index, Modelling.

RASĀYAN J. Chem., Vol. 14, No.3, 2021

\section{INTRODUCTION}

Water is an indispensable natural resource on the planet. Healthy drinking water is a human being's primary requirement. Owing to over-exploitation and wastewater discharge, freshwater has become a precious asset. The risk of river water pollution is due to the mixing of hazardous materials, fertilizers and unsafe processing of agricultural liquid waste. Numerous human exercises and their side-effects can affect surface and subsurface water without fitting waste administration methodologies. ${ }^{1}$ The quality assessment of transitional water is regarded as an important extension of such studies about the assessment of environmental quality. ${ }^{2}$

Polluting materials released into the water resources leads to deteriorating the quality of water which majorly impacts the freshwater bodies and marine ecosystems. Evaluating and comparing the water quality with standards are consequential for supervising and enhancing the water quality. ${ }^{3,4}$

The water quality index is quite possibly the best apparatuses to convey facts on the quality of water to the concerned people. It, hence, turns into a significant boundary for the evaluation and management of surface water. WQI is characterized as a ranking mirroring the complex impact of diverse river quality properties. WQI is determined from the perspective of the suitability of surface water for social utilization. ${ }^{5}$

The ANN strategy is adequately adaptable to oblige extra limitations that may emerge during its application. Also, the ANN model can uncover concealed connections in authentic information, in this way encouraging the prediction and anticipating of water quality. ${ }^{6}$ Artificial neural organizations for foreseeing the water quality segments in a few contextual investigations. The author had expressed that artificial intelligence methods have appropriate execution for modeling and foreseeing the inward connection between the water quality parts and demonstrating their time arrangement. Assessing and predicting water quality proves to be an important factor for water conservation and development projects and artificial intelligence techniques have been proposed for modeling the water quality. ${ }^{7,8}$

Rasayan J. Chem., 14(3), 1910-1919(2021)

http://doi.org/10.31788/RJC.2021.1436358

This work is licensed under a CC BY 4.0 license. 
RASĀYAN J. Chem.

Vol. 14 | No. 3 |1910-1919| July - September | 2021

The main purpose of this study is to calculate WQI based on the physical and chemical parameters and to develop ANN model to assess the water quality of Tamiraparani River. The model can be used for understanding and managing water quality.

\section{Study Area and Data}

The sample was collected from 12 major places they are Papanasam, Cheranmadevi, Kokirakulam, Murapanadu, Thiruvidaimarudur, Ambasamudram, Authoor, Eral, Kallidai Kurichi, Srivaikuntam, Vellakovil and Sivalaperi. Parameters were analyzed for the water quality of Tamiraparani river is $\mathrm{pH}$, turbidity, alkalinity, chloride, hardness, calcium, magnesium and TDS. All the parameters were measured in $\mathrm{mg} / \mathrm{l}$ except for $\mathrm{pH}$ and turbidity. $\mathrm{pH}$ has no unit and turbidity was measured in NTU.

Table-1: Water Quality for Selected Area during pre-monsoon

\begin{tabular}{c|c|c|c|c|c|c|c|c}
\hline & $\mathrm{pH}$ & Turbidity & Alkalinity & Chloride & Hardness & Calcium & Magnesium & TDS \\
\hline Min & 6.5 & 2.22 & 4 & 6 & 12 & 3.2 & 0.97 & 28 \\
\hline Max & 7.1 & 8.08 & 68 & 125 & 218 & 56 & 19 & 380 \\
\hline Mean & 6.8 & 4.739 & 18.17 & 32 & 65.5 & 19.3 & 4.193 & 104.33 \\
\hline Median & 6.75 & 4.095 & 10 & 14.5 & 49 & 14.5 & 2.675 & 67 \\
\hline Mode & 6.7 & - & 4 & 8 & 50 & 9.6 & 0.97 & - \\
\hline $\begin{array}{c}\text { Standard } \\
\text { Deviation }\end{array}$ & 0.18 & 2.119 & 20.08 & 36.868 & 59.409 & 16.816 & 5.003 & 105.73 \\
\hline Variance & 0.03 & 4.49 & 403.24 & 1359.27 & 3529.6 & 282.79 & 25.035 & 11178.1 \\
\hline
\end{tabular}

Tamiraparani River plays significant role in marine resources in Tirunelveli and Tuticorin districts. This river originates from Agastiar foothill of Western Ghats, and spreads towards the Bay of Bengal Punnaikayal and Pazhayakayal Estuarine, part of Gulf of Mannar. Study area Tamiraparani Estuarine is located between latitude 8.641316N and longitude 78.127298E. Samples were collected during early morning time of pre-and post-monsoon. All parameters were estimated in the laboratory by using standard methods as prescribed by WHO. The obtained values were tabulated as in Tables- 1 and 2.

Table-2: Water Quality for Selected Area during post-monsoon

\begin{tabular}{c|c|c|c|c|c|c|c|c}
\hline & $\mathrm{pH}$ & Turbidity & Alkalinity & Chloride & Hardness & Calcium & Magnesium & TDS \\
\hline Min & 6.3 & 0.48 & 2 & 5.11 & 8 & 1.6 & 0.97 & 16 \\
\hline Max & 7.16 & 8.6 & 23.4 & 63 & 65 & 21 & 2.65 & 115 \\
\hline Mean & 6.7 & 2.45 & 9.66 & 18.33 & 21.25 & 6.85 & 1.29 & 47 \\
\hline Median & 6.7 & 2.08 & 7 & 11.23 & 12 & 2.4 & 0.97 & 33 \\
\hline Mode & 6.8 & 2.11 & 4 & 11.23 & 12 & 1.6 & 0.97 & 16 \\
\hline $\begin{array}{c}\text { Standard } \\
\text { Deviation }\end{array}$ & 0.3 & 2.21 & 7.06 & 16.44 & 17.73 & 7.05 & 0.54 & 36.5 \\
\hline Variance & 0.1 & 4.89 & 49.81 & 270.5 & 314.20 & 49.68 & 0.295 & 1333.6 \\
\hline
\end{tabular}

\section{Methodology}

Along the waterway, twelve sites were carefully chosen for sampling. The pre-sterilized bottles were used for the collection of water samples from each site during two spells, i.e., pre-monsoon (August to October), post-monsoon (January to February) throughout 2019-2020. Field kits were used for measurements of $\mathrm{pH}$ and TDS. Till the analysis work was started in the laboratory, the samples were kept in a freezer at $4^{\circ} \mathrm{C}$. 0.45 -micron filters were used to remove the suspended particles in the samples and then they were analysed using standard procedures. ${ }^{9}$

To calculate water quality index, the sub-index (SI) needs to be determined for each water quality constraint, as mentioned below: ${ }^{10}$

Where,

$$
\text { SIi }=\text { Wi X qi }
$$

$\mathrm{q}_{\mathrm{i}}$ - quality rating,

$\mathrm{C}_{\mathrm{i}}$ - concentration of each parameter in $\mathrm{mg} / \mathrm{l}$,

$\mathrm{S}_{\mathrm{i}}$ - Indian drinking water standard in $\mathrm{mg} / \mathrm{l}$. 
WQI is calculated using the below equation,

Where,

$$
\mathrm{WQI}=\sum \mathrm{SI}_{\mathrm{i}}-\mathrm{n}
$$

$$
\begin{aligned}
& S I_{i}-\text { sub-index of } i^{\text {th }} \text { parameter } \\
& W_{i} \text { - relative weight of } i^{\text {th }} \text { parameter } \\
& q_{i} \text { - rating of } i^{\text {th }} \text { parameter based on the concentration } \\
& n \text { - number of chemical parameters }
\end{aligned}
$$

The statistical investigation was performed using SPSS software program to find the correlation coefficient which can be used for understanding the behaviour of the parameters.

ANNs were also utilized in water quality investigation and estimation. To enable modeling of nonlinear water quality parameters, feed-forward back-propagation training algorithm has been used with one or more hidden layers. A different set of input parameters were considered for the targeted parameter TDS.

\section{pH}

\section{RESULTS AND DISCUSSION}

If the $\mathrm{pH}$ is under 6.5 , it suspends the creation of nutrients and minerals in the human body. If the $\mathrm{pH}$ is more than 8.5, it makes the water saltier. And the water causes eyes disorder and skin problems if $\mathrm{pH}$ is more than 11 . For the $\mathrm{pH}$ of $5.5-6$, the rainwater doesn't have any useful minerals and is unsafe to be utilized for drinking purposes. ${ }^{11}$ In this study, $\mathrm{pH}$ was measured with $\mathrm{pH}$ electrode for pre-and postmonsoon. In Papanasam and Murapanadu, $\mathrm{pH}$ values are lesser than 6.5 in pre-monsoon and the values are not within the permissible limits.

\section{Turbidity}

The higher turbidity in water impedes the entrance of light. This will harm the aquatic life and fall apart the nature of the surface water. ${ }^{12}$ In this study turbidity values are measured on Nephelo turbidity meter for preand post-monsoon for the selected locations. Throughout pre-monsoon, the turbidity is higher in Authoor location and during post-monsoon, it was higher in Kokirakulam, Vellakovil and Sivalaperi.

\section{Alkalinity}

Total alkalinity throughout the study area ranges from $2 \mathrm{mg} / 1$ to $23.4 \mathrm{mg} / 1$ in pre-monsoon and varies from $4 \mathrm{mg} / 1$ to $68 \mathrm{mg} / 1$ in post-monsoon especially higher at Authoor.

\section{Chloride}

Chloride is a normally happening component that is present in waters and is frequently found as a part of salt (sodium chloride) or sometimes in blend with potassium or calcium. ${ }^{13}$ Chloride in a water sample for all twelve locations within the permissible limit but compared to other locations Authoor has more chloride in pre- and post-monsoon.

\section{Hardness}

The hardness was higher in post-monsoon $218 \mathrm{mg} / \mathrm{l}$ at Authoor location and lower in pre-monsoon $8 \mathrm{mg} / \mathrm{l}$ at papanasam. Calcium ions make a major contribution to the hardness of river water.

\section{Calcium}

During pre-monsoon presence of calcium in water varies from $1.6 \mathrm{mg} / 1$ to $21 \mathrm{mg} / 1$. Similarly, calcium was observed in water from $3.2 \mathrm{mg} / 1$ to $56 \mathrm{mg} / 1$ during post-monsoon. Higher presence of calcium observed in Authoor location during both pre-and post-monsoon. The concentration of Calcium was always greater than that of magnesium. ${ }^{14}$

\section{Magnesium}

Magnesium substance of water is considered as one of the main parameters in deciding the nature of water for agriculture usage. ${ }^{15}$ In the current investigation, the magnesium substance of the water of the river changes from $0.97 \mathrm{mg} / 1$ to $19 \mathrm{mg} / \mathrm{l}$, which is reasonable for irrigation. 
RASĀYAN J. Chem.

Vol. 14 | No. 3 |1910-1919| July - September | 2021

\section{Total Dissolved Solids (TDS)}

TDS are more significant estimations to be regarded when analyzing water quality. High TDS esteems makes unsafe impact the general wellbeing. ${ }^{16}$ It decides the reasonableness of water for horticulture uses. The scope of TDS falls between $16 \mathrm{mg} / 1$ to $115 \mathrm{mg} / \mathrm{l}$ in pre-rainstorm and $28 \mathrm{mg} / 1$ to $380 \mathrm{mg} / \mathrm{l}$ in poststorm. Overall, the TDS in water inside allowable constraint of $500 \mathrm{mg} / \mathrm{l}$. The results of seasonal variation of water quality in Tamiraparani river can see in Fig.-1.

\section{Water Quality Index}

The observations in the current study briefed as WQI ranged from 16.87 to 135.60 before the rainy season and 40.53 to 122.15 after the rainy season. Based on WQI, the water quality at Authoor is poor during the pre-wet season as well as post-wet season. During rainy season the quality of water the downstream is poor due to the mixing of solid waste and domestic wastewater.

The percentage of variation in water quality is represented in Table-3.

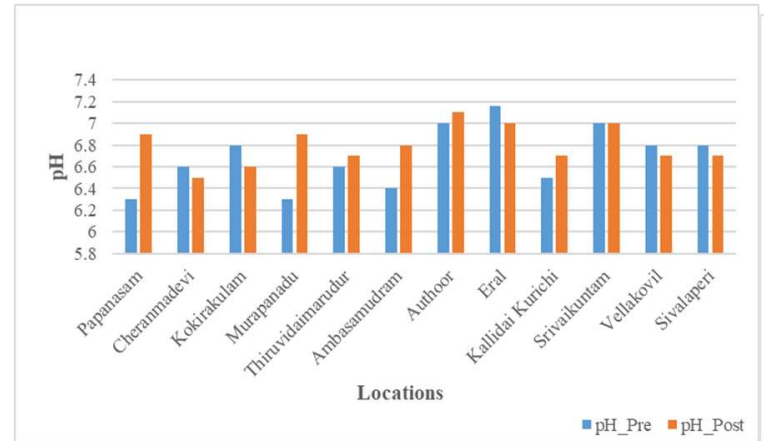

(a)

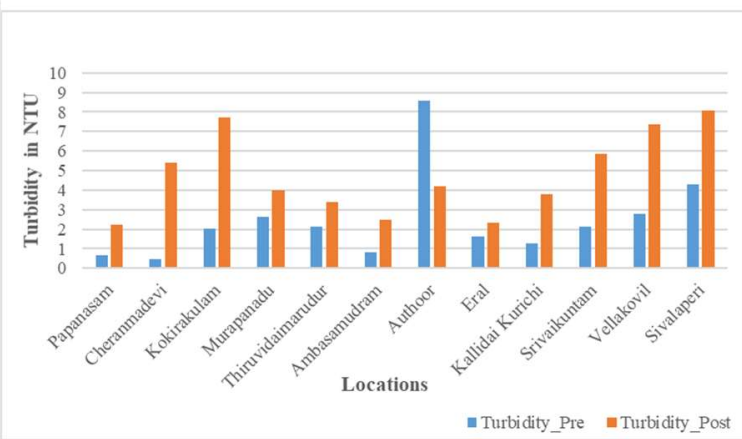

(b)

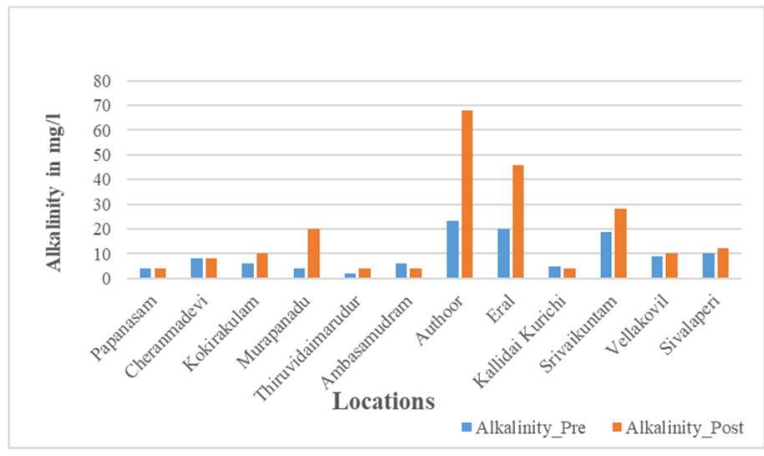

(c)

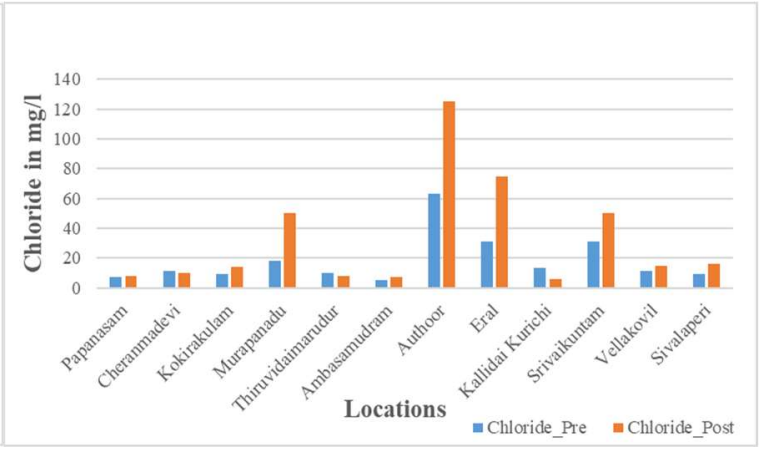

(d)

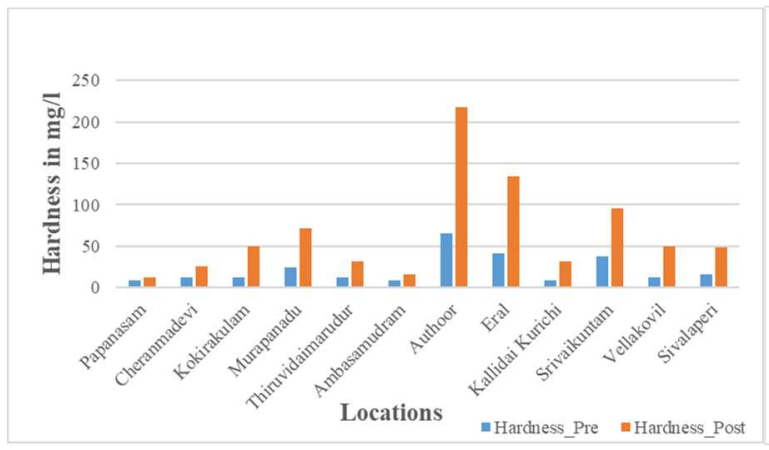

(e)

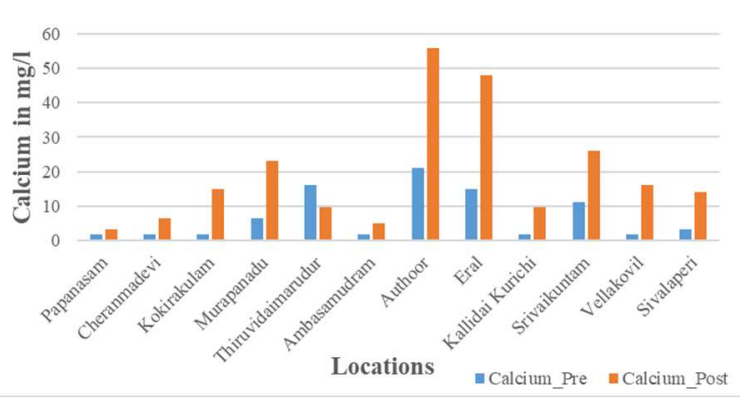

(f) 
RASĀYAN J. Chem.

Vol. 14 | No. 3 |1910-1919| July - September | 2021

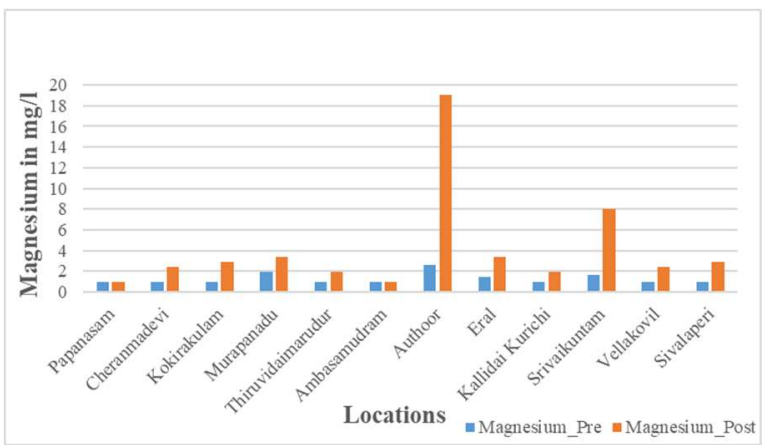

(g)

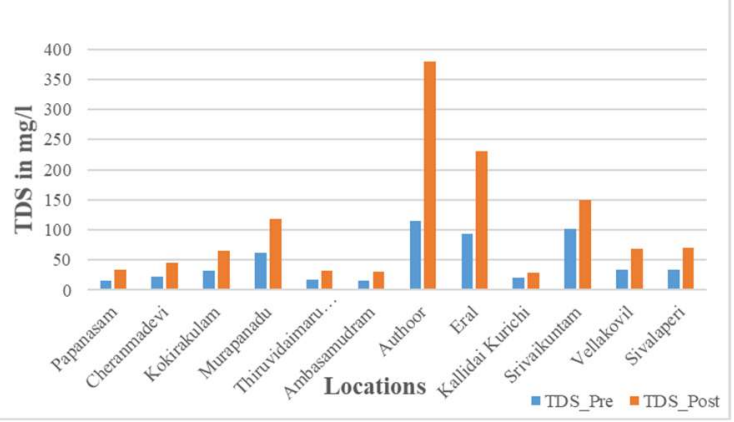

(h)

Fig.-1: Seasonal Variation of water quality in Tamiraparani River for (a) pH, (b) Turbidity, (c) Alkalinity, (d) Chloride, (e) Hardness, (f) Calcium, (g) Magnesium and (h) TDS

Table-3: Water Quality Index (WQI) range and percentage of different water types

\begin{tabular}{c|c|c|c}
\hline \multirow{2}{*}{ WQI Range } & \multirow{2}{*}{ Water Type } & \multicolumn{2}{|c}{ Percentage of Samples } \\
\cline { 3 - 4 } & & Pre-monsoon & Post-monsoon \\
\hline$<50$ & Excellent Water & 83.3 & 16.7 \\
\hline $50-100$ & Good Water & 8.3 & 41.7 \\
\hline $100-200$ & Poor Water & 8.3 & 41.7 \\
\hline $200-300$ & Very Poor Water & 0 & 0 \\
\hline$>300$ & Not suitable for Drinking & 0 & 0 \\
\hline
\end{tabular}

The decision-making about the quality of water is a crucial issue because of the number of parameters involved in drinking water quality. Based on the water quality index better decisions can make about the quality of water in any region. ${ }^{17}$ The comparison of water quality index between pre-monsoon and postmonsoon is shown in Fig.-2.

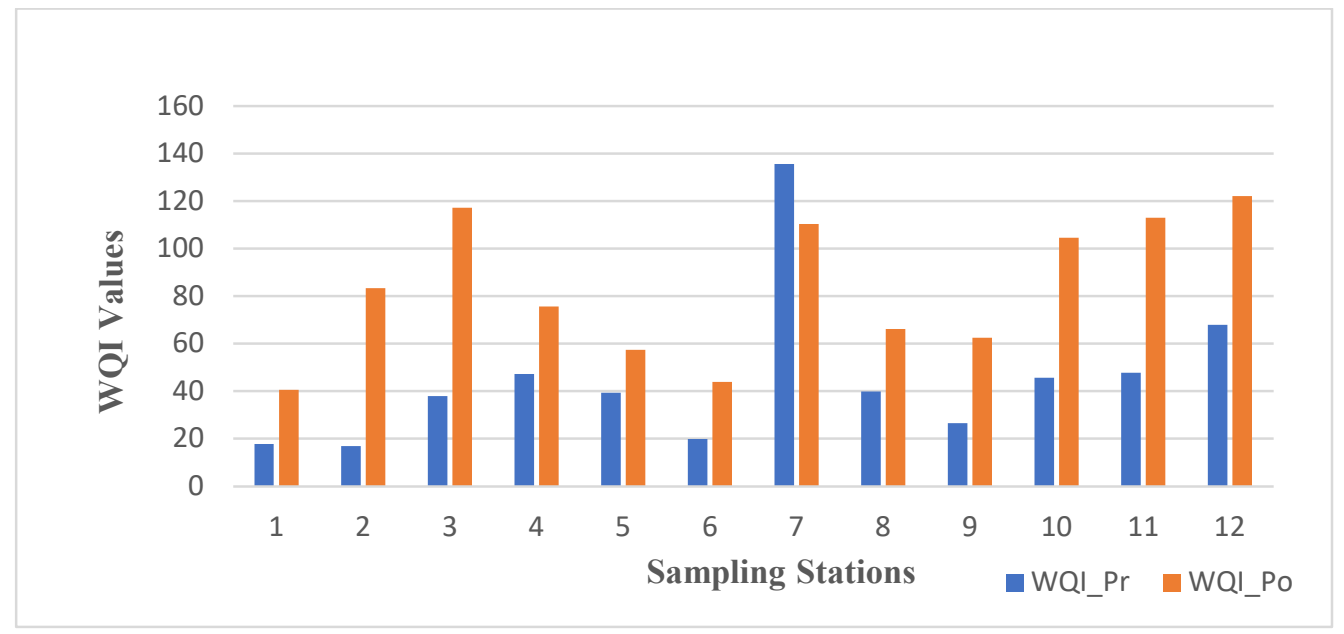

\section{Correlation Analysis}

Fig.-2: WQI in pre-monsoon and post-monsoon

In this examination, the relationship grid of 8 parameters for before and after rainstorm periods was figured utilizing SPSS programming. The simple correlation coefficient which is widely used shows the ability of one variable to forecast the additional variable. The correlation coefficient of the water quality parameter for pre-monsoon is shown in Table-4.

The connection between the parameters before and after seasonal rainfall has demonstrated roughly a closely resembling pattern. Strong $(r=0.9)$ to good $(r=0.9$ to 0.5$)$ relationships among the different 
RASĀYAN J. Chem.

Vol. 14 | No. 3 |1910-1919| July - September | 2021

Physicochemical characters have been detected. Hardness and TDS are strongly corresponded (pre-storm $\mathrm{r}$ $=0.955$; post-rainstorm $\mathrm{r}=0.993$ ).

The correlation coefficient of the water quality parameter for post-monsoon is shown in Table-5.

Table-4: Correlation Coefficient for pre-monsoon water quality

\begin{tabular}{c|c|c|c|c|c|c|c|c}
\hline & $\mathrm{pH}$ & Turbidity & Alkalinity & $\mathrm{Cl}$ & Hardness & $\mathrm{Ca}$ & $\mathrm{Mg}$ & $\mathrm{TDS}$ \\
\hline $\mathrm{pH}$ & 1 & & & & & & & \\
\hline Turbidity & 0.45269 & 1 & & & & & & \\
\hline Alkalinity & 0.84188 & 0.589831 & 1 & & & & & \\
\hline Chloride & 0.61079 & 0.771781 & 0.862022 & 1 & & & & \\
\hline Hardness & 0.67137 & 0.745015 & 0.899519 & 0.97702 & 1 & & & \\
\hline Calcium & 0.55950 & 0.605744 & 0.640702 & 0.80292 & 0.82443 & 1 & & \\
\hline Magnesium & 0.33908 & 0.749775 & 0.67429 & 0.91181 & 0.90679 & 0.7106 & 1 & \\
\hline TDS & 0.70417 & 0.606223 & 0.89963 & 0.90381 & 0.95455 & 0.7368 & 0.8593 & 1 \\
\hline
\end{tabular}

Table-5: Correlation Coefficient for post-monsoon water quality

\begin{tabular}{c|c|c|c|c|c|c|c|c}
\hline & $\mathrm{pH}$ & Turbidity & Alkalinity & $\mathrm{Cl}$ & Hardness & $\mathrm{Ca}$ & $\mathrm{Mg}$ & $\mathrm{TDS}$ \\
\hline $\mathrm{pH}$ & 1 & & & & & & & \\
\hline Turbidity & -0.45434 & 1 & & & & & & \\
\hline Alkalinity & 0.75574 & -0.12437 & 1 & & & & & \\
\hline Chloride & 0.79054 & -0.16436 & 0.988723 & 1 & & & & \\
\hline Hardness & 0.72573 & -0.04984 & 0.989784 & 0.98290 & 1 & & & \\
\hline Calcium & 0.72854 & -0.09386 & 0.978474 & 0.96341 & 0.97730 & 1 & & \\
\hline Magnesium & 0.62078 & 0.043141 & 0.866357 & 0.87711 & 0.89809 & 0.78477 & 1 & \\
\hline TDS & 0.75287 & -0.10721 & 0.996808 & 0.9915 & 0.99306 & 0.96903 & 0.894615 & 1 \\
\hline
\end{tabular}

After wet season TDS strongly correlated with alkalinity, chloride, hardness and calcium. In the same way alkalinity strongly correlated with chloride, hardness and calcium.

\section{Modeling}

ANN model architecture refers to the quantity of layers hidden and the layout of neurons. In most of the engineering, application feed-forward back-propagation training algorithm is used. In this work ANN model with a back-propagation algorithm is constructed to predict TDS values.

\section{Pre-Monsoon}

In the first model, $\mathrm{pH}$ and Turbidity were provided as input and targeted parameter TDS. While analyzing the data for the pre-monsoon period, the parametric studies on $\mathrm{pH}$ and turbidity are correlated with TDS which is the target parameter, and the graphical illustration is represented in the graph. In Fig.-3, it is observed that the TDS parameter correlated with input parameters shows an almost closer fit with $\mathrm{R}=0.80836$.

In the next model, $\mathrm{pH}$, Turbidity and Alkalinity were provided as input, with targeted parameter TDS in pre-monsoon. In Fig.-4, it is observed that the TDS parameter correlated with input parameters shows an almost closer fit with $\mathrm{R}=0.95365$.

In the third model, $\mathrm{pH}$, Turbidity, Alkalinity and chlorides were provided as input from pre-monsoon data and targeted with TDS. In Fig.-5, it is observed that the TDS parameter correlated with input parameters shows an almost closer fit with $\mathrm{R}=0.93696$.

In the fourth model, $\mathrm{pH}$, Turbidity, Alkalinity, chlorides and Hardness were provided as input, with targeted value TDS. In Fig.-6, it is observed that the TDS parameter correlated with input parameters shows an almost closer fit with $\mathrm{R}=0.88544$.

In the fifth model, $\mathrm{pH}$, Turbidity, Alkalinity, chlorides, Hardness and calcium used as input in ANN and targeted value as TDS. In Fig.-7 it is observed that the TDS parameter correlated with input parameters show an almost closer fit with $\mathrm{R}=0.96772$.

In the final model, input data is provided as $\mathrm{pH}$, Turbidity, Alkalinity, chlorides, Hardness, calcium and 
RASĀYAN J. Chem.

Vol. 14 | No. 3 |1910-1919| July - September | 2021

magnesium with targeted parameter TDS. In Fig.-8, it is observed that the TDS parameter correlated with input parameters shows an almost closer fit with $\mathrm{R}=0.94758$.

\section{Post-Monsoon}

In the first model in post-monsoon, $\mathrm{pH}$ and Turbidity were fed as input and targeted parameters as TDS. It is observed in Fig.-9, the TDS parameter correlated with input parameters shows an almost closer fit with $\mathrm{R}=0.8405$.

In the second model, $\mathrm{pH}$, Turbidity and Alkalinity were provided as input, with targeted parameter TDS in post-monsoon. It is observed in Fig.-10, that the TDS parameter correlated with input parameters shows an almost closer fit with $\mathrm{R}=0.96744$.
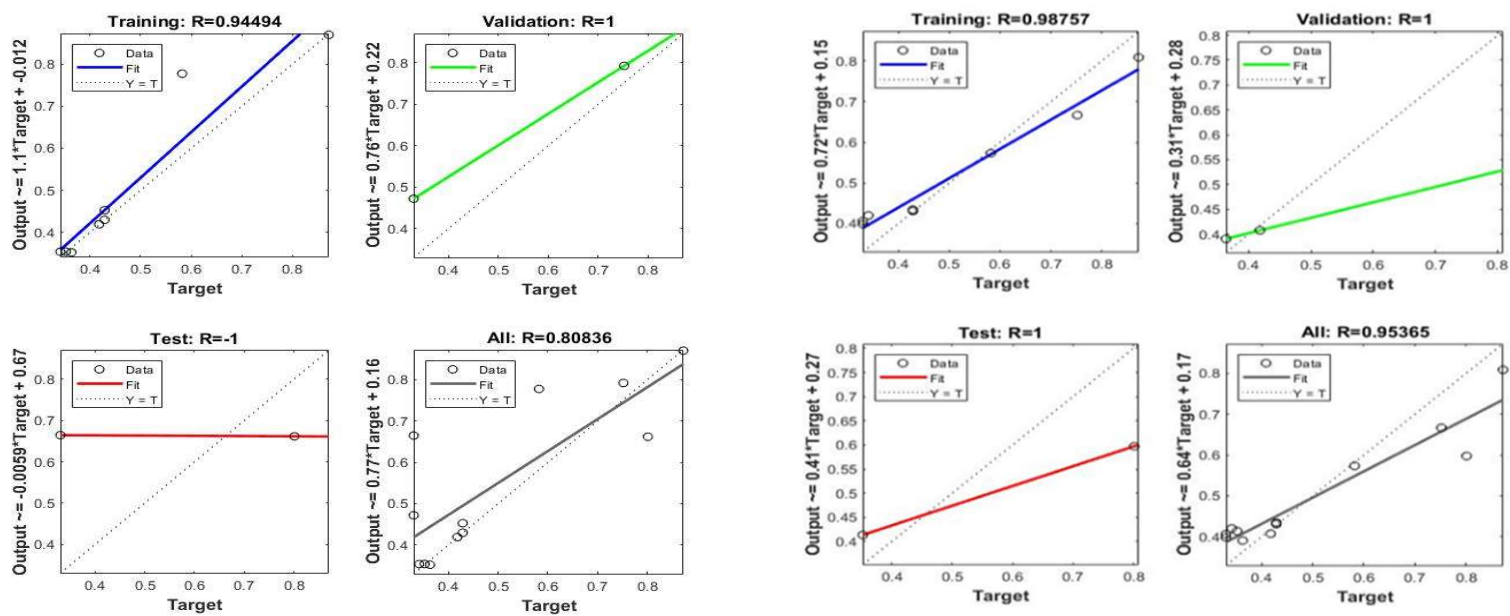

Fig.-3: Comparison between NN outputs and targets for training and test data
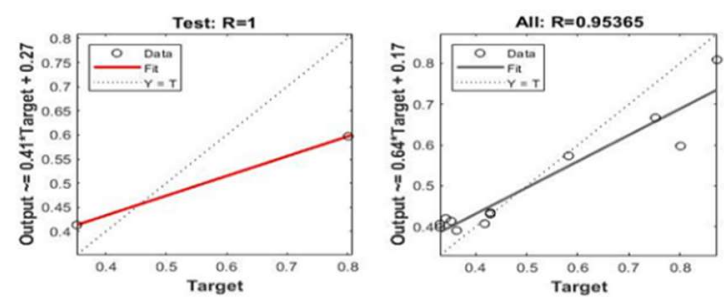

Fig.-4: Comparison of predicted ANNs time series with observed values
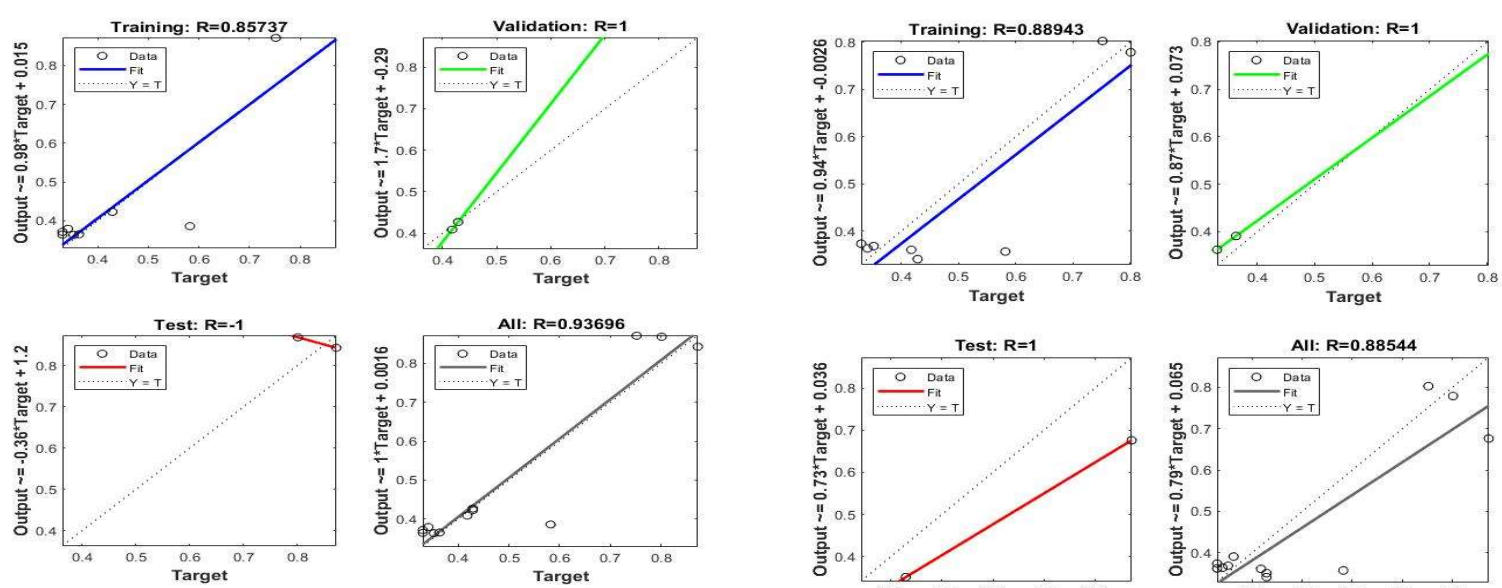

Fig.-5: Comparison of predicted ANNs time series with observed values
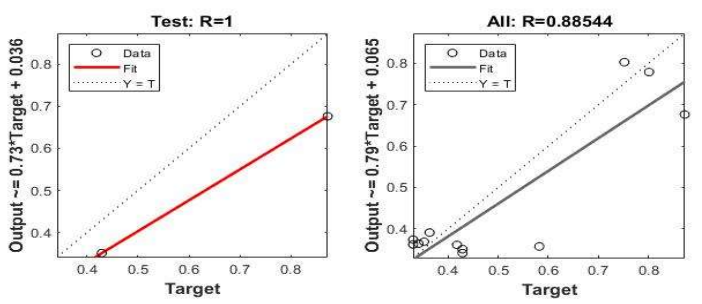

Fig.-6: Comparison between NN outputs and targets for training and test data 
RASĀYAN J. Chem.

Vol. 14 | No. 3 |1910-1919| July - September | 2021
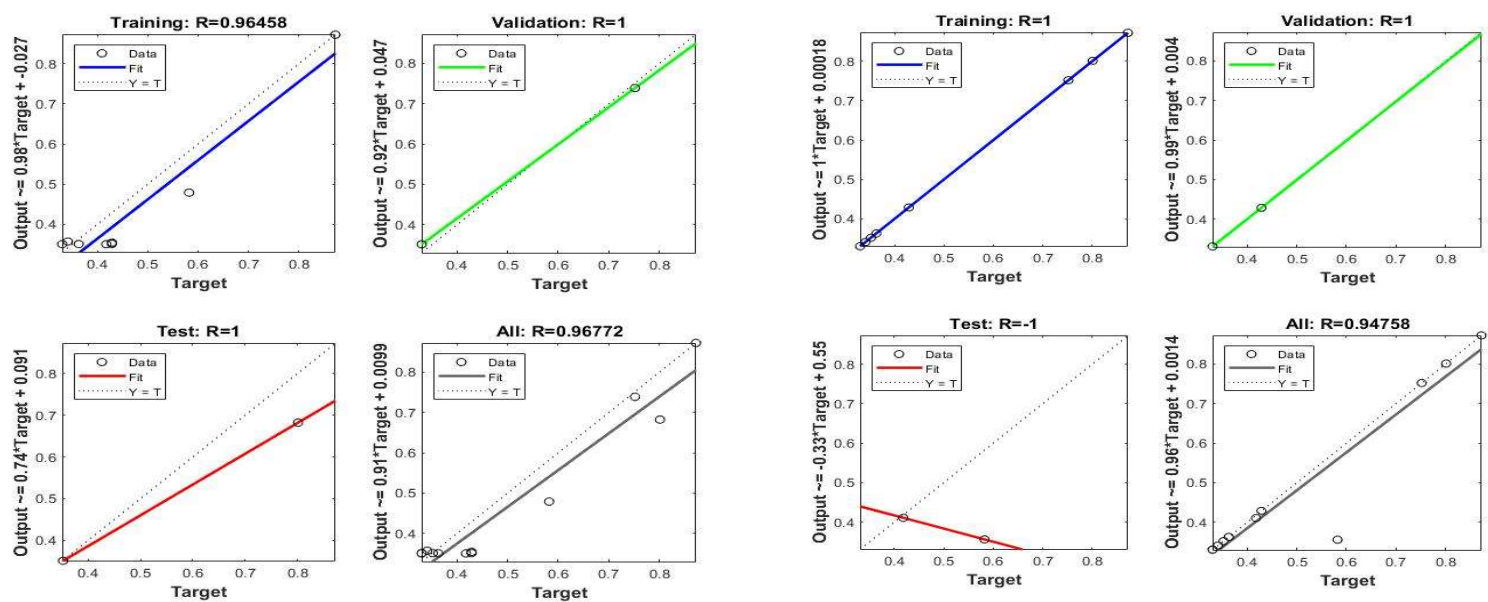

Fig.-7: Comparison between NN outputs and targets for training and test data
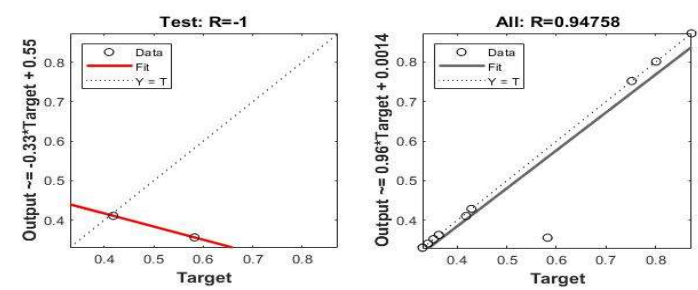

Fig.-8: Comparison of predicted ANNs time series with observed values
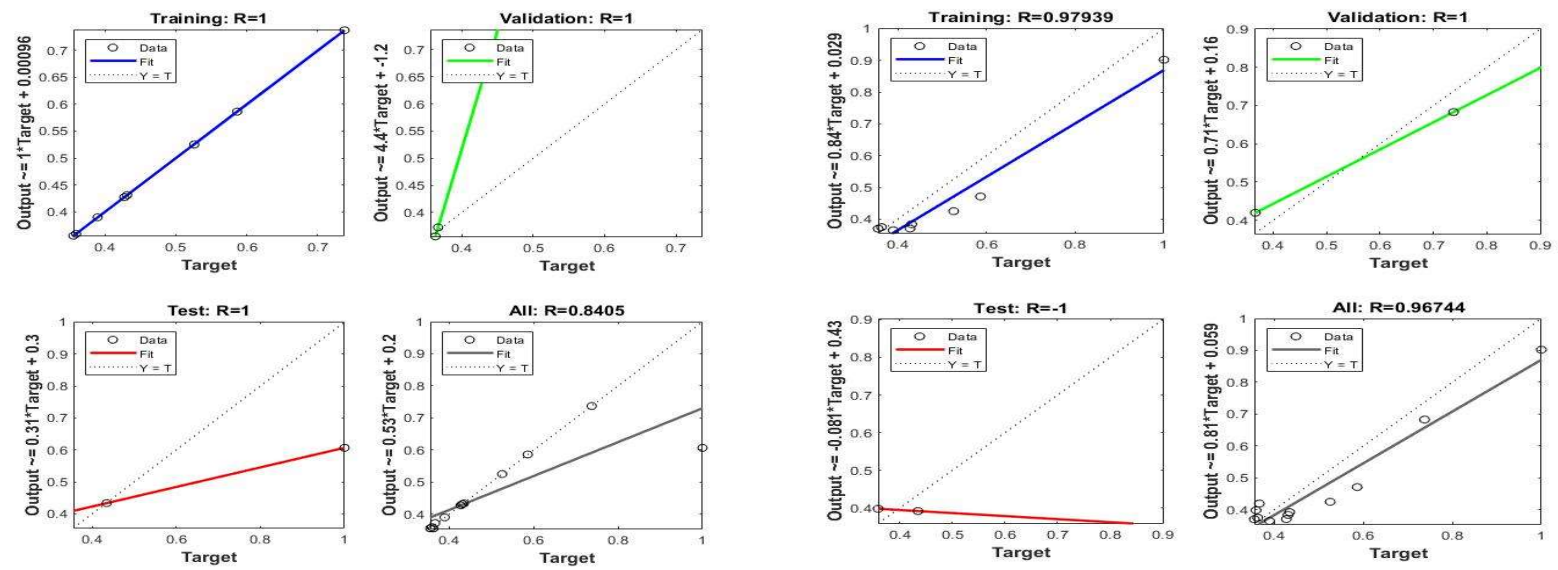

Fig.-9: Comparison of predicted ANNs time series with observed values
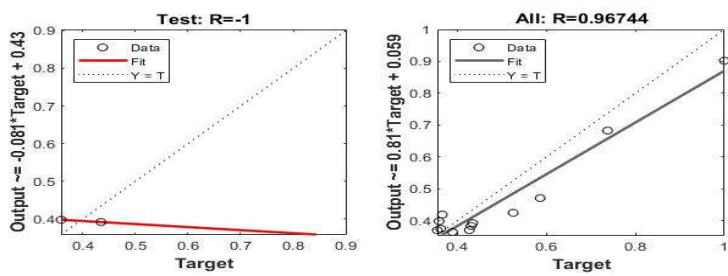

Fig.-10: Comparison between NN outputs and targets for training and test data
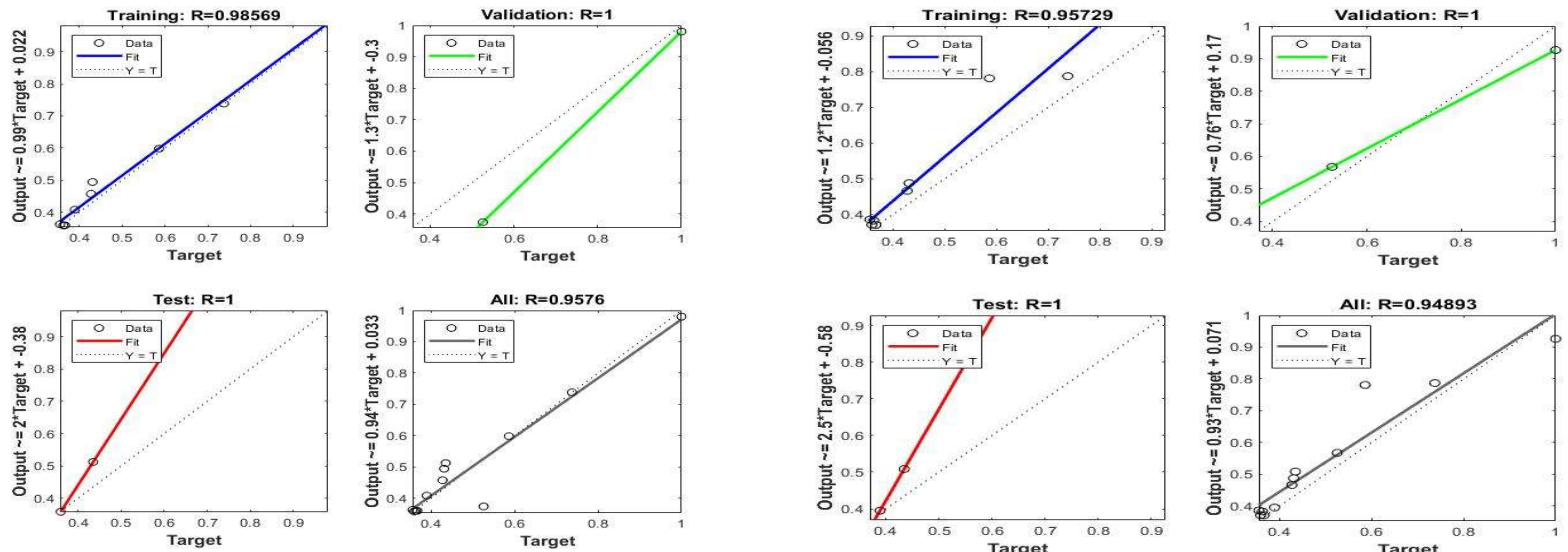

Fig.-11: Comparison between NN outputs and targets for training and test data
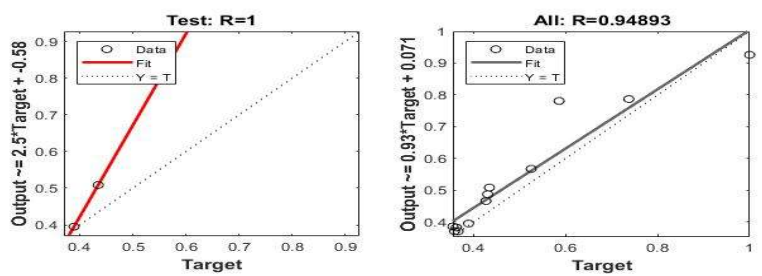

Fig.-12: Comparison of predicted ANNs time series with observed values 

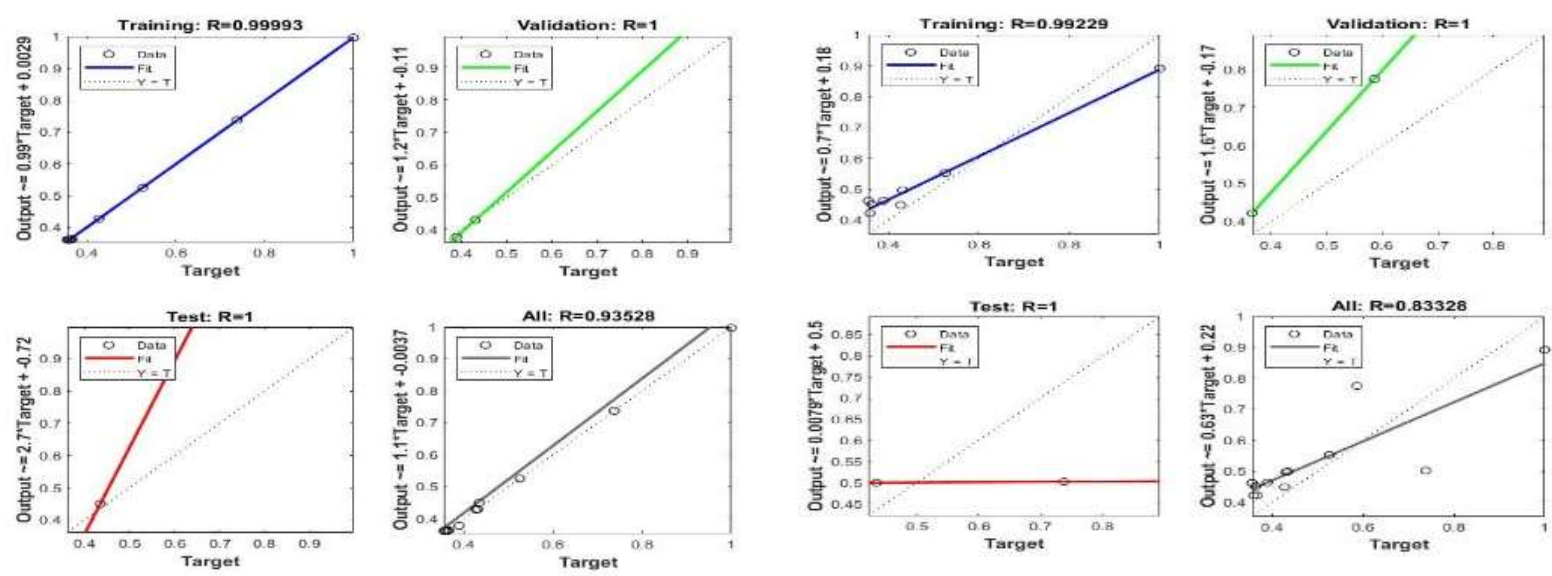

Fig.-13: Comparison of predicted ANN time series with observed values.

Fig.-14: Comparison between NN outputs and targets for training and test data

In the third model $\mathrm{pH}$, Turbidity, Alkalinity and chlorides were taken as input from post-monsoon data and targeted with TDS. It is observed in Fig.-11, that the TDS parameter correlated with input parameters shows an almost closer fit with $\mathrm{R}=0.9576$.

In the fourth model, $\mathrm{pH}$, Turbidity, Alkalinity, chlorides and Hardness were considered as input, with targeted value as TDS. It is observed in Fig.-12, that the TDS parameter correlated with input parameters shows an almost closer fit with $\mathrm{R}=0.94893$.

In the fifth model, $\mathrm{pH}$, Turbidity, Alkalinity, chlorides, Hardness and calcium were used as inputs in ANN and targeted value as TDS. In Fig.-13, it is observed that the TDS parameter correlated with input parameters shows an almost closer fit with $\mathrm{R}=0.93528$.

In the final model, $\mathrm{pH}$, Turbidity, Alkalinity, chlorides, Hardness, calcium and magnesium were fed into ANN as input and TDS as a targeted parameter. It is observed in Fig.-14, that the TDS parameter correlated with input parameters shows an almost closer fit with $\mathrm{R}=0.83328$.

\section{CONCLUSION}

The preliminary concern for analyzing the water quality is to evaluate the effect of polluting materials that are released into the water resources leading to water quality deterioration which majorly impacts the freshwater bodies and marine ecosystems. The research analysis was performed across the Tamiraparani river basin. The water quality of the Tamiraparani river was predicted by an Artificial Neural Network model with a different set of input data and targeted parameter TDS.

In this examination, the calculated value of WQI fluctuated between 16.87 to 135.60 for pre-rainstorm and 40.53 to 122.15 for the post-storm season. As indicated by the WQI estimations, water quality at one area in pre-monsoon and five areas in post-monsoon periods was discovered inadmissible for drinking. High turbidity and TDS content were responsible for higher WQI values noted at the destinations inspected. The grouping of chloride and hardness additionally was a huge component for high WQI values at certain spots during the post-rainstorm period. The WQI shows that "great water" exists in the region during prerainstorm and "bad quality water" during the post-storm period. This proposes that a more noteworthy measure of draining and invasion of contaminations should be implemented for better water quality.

\section{REFERENCES}

1. S. W. Lee, S. J. Hwang, S. B. Lee, H. S. Hwang and H. C. Sung, Landscape and Urban Planning, 92(2), 80(2009), https://doi.org/10.1016/j.landurbplan.2009.02.008

2. R. Batool, K. Mahmood, S. R. Ahmad and M. A. Naeem, Applied Ecology and Environmental Research, 17(2), 3973(2019), https://doi.org/10.15666/aeer/1702 39733988

3. Z. Shen, X. Hou, W. Li and G. Aini, Landscape and Urban Planning, 123, 96(2014), 
RASĀYAN J. Chem.

Vol. 14 | No. 3 |1910-1919| July - September | 2021

https://doi.org/10.1016/j.landurbplan.2013.12.007

4. A. C. Pandey and A. Kumar, Applied Water Science, 5(1), 13(2015), https://doi.org/10.1007/s13201014-0165-y

5. J. V. Morin, B. Mansoben, M. Infaindan, F. L. Ayer, Marty, L. L. Mandosir, J. O. Ughude, D. Awendu, R. Yarangga, P. Patulak, P. Noya, and D. Santi, Rasayan Journal of Chemistry, 14(1), 454(2021), http://dx.doi.org/10.31788/RJC.2021.1416111

6. A. Najah, A. El-Shafie, O. A. Karim and H. El-Shafie, Springer-Neural Computing and Applications, 22(1), 187(2013), https://doi.org/10.1007/s00521-012-0940-3

7. Deepak Kumar, Vinay Kumar and Sangeeta Kumari, Rasayan Journal of Chemistry, 11(4), 1477(2018), http://dx.doi.org/10.31788/RJC.2018.1143075

8. D. Justus Reymond, Karuppasamy Sudalaimuthu and P. Sakthi Maheswaran, AIP Conference Proceedings, 2277, 180001(2020), https://doi.org/10.1063/5.0025397

9. Y. Zhang, C. Chu , T. Li, S. Xu, L. Liu and M. Ju, Science of the Total Environment, 599, 721(2017), https://doi.org/10.1016/j.scitotenv.2017.04.232

10. R. K. Yadav and M. R. Augur, Rasayan Journal of Chemistry, 11(2), 537(2018), https://doi.org/10.31788/RJC.2018.1122089

11. O. S. Malar, P. Kokila and C. I. S Raj, International Journal of Scientific Research and Management, 6(10), 111(2018), https://doi.org/10.18535/ijsrm/v6i10.fe03

12. F. Ustaoğlu and Y. Tepe, International Soil and Water Conservation Research, 7(1), 47(2019), https://doi.org/10.1016/j.iswcr.2018.09.001

13. P. S. Bytyçi, F. N. Zhushi Etemi, M. A. Ismaili, Sh. A. Shala, M. S. Serbinovski, H. S. Çadraku and O. B. Fetoshi, Rasayan Journal of Chemistry, 11(2), 554(2018), https://doi.org/10.31788/RJC.2018.1122087

14. Hatim Elhatip and M. Aydin Komur, Environmental Geology, 53, 1157(2008), https://doi.org/10.1007/s00254-007-0705-y

15. G. J. Chakrapani, R. K. Saini and S. K. Yadav, Journal of Asian Earth Science, 34(3), 347(2009), https://doi.org/10.1016/j.jseaes.2008.06.002

16. V. H. McNeil and M. E. Cox, Journal of Environment Geology, 39(12), 1325(2000), https://doi.org/10.1007/s002549900033

17. D. Justus Reymond, J. S. Sudarsan, K. Prasanna and Helen Sheebha, Rasayan Journal of Chemistry, 9(3), 319(2016).

[RJC-6358/2021] 